\title{
Transatlantica
}

Revue d'études américaines. American Studies Journal

\section{Tamar Stone's Art: Rewriting the Female Body}

\section{Candela Delgado-Marín}

\section{(2) OpenEdition}

\section{Journals}

Electronic version

URL: https://journals.openedition.org/transatlantica/6437

DOI: 10.4000/transatlantica.6437

ISSN: $1765-2766$

\section{Publisher}

Association française d'Etudes Américaines (AFEA)

\section{Electronic reference}

Candela Delgado-Marín, "Tamar Stone's Art: Rewriting the Female Body", Transatlantica [Online], 1 | 2013, Online since 09 July 2014, connection on 31 January 2023. URL: http://

journals.openedition.org/transatlantica/6437 ; DOI: https://doi.org/10.4000/transatlantica.6437

This text was automatically generated on 31 January 2023.

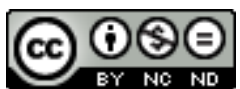

Creative Commons - Attribution-NonCommercial-NoDerivatives 4.0 International - CC BY-NC-ND 4.0 https://creativecommons.org/licenses/by-nc-nd/4.0/ 


\title{
Tamar Stone's Art: Rewriting the Female Body
}

\author{
Candela Delgado-Marín
}

All of the pictures in this article are reproduced courtesy of Tamar Stone. Many thanks to her.

The basic Female Body comes with the following accessories: garter belt, panty-girdle, crinoline, camisole, bustle, brassiere, stomacher, chemise, virgin zone, spike heels, nose ring, veil, kid gloves, fish-net stockings, fichu, bandeau, Merry Widow, weepers, chokers, barrettes, bangles,

beads, lorgnette, feather boa, basic black, compact, Lycra stretch one-piece with modesty panel, designer peignoir, flannel nightie, lace teddy, bed, head. (Atwood, 1)

The body of a woman, immediately after entering the world, is paired with appendages that eclipse the mainstay. The embellished additions modify the female natural semblance and shape it to accommodate men's sexual desires and preconceptions of femininity. The above derisible inventory created by Margaret Atwood depicts this corporeal identity as a doll to be purchased with interchangeable garments. The items infuse into the body the gender stereotypes associated with women throughout their existence: voluptuous shapes of motherhood, lithe figure of frail damsel in distress, sexually provocative underwear complemented with chaste outerwear to portray desire and virginity simultaneously, funeral dresses to welcome the posthumous and perpetual mark of male property; all of which turn her into a walking provider of sensual stimulation. Atwood includes the bed as the resting place to anchor women to the home and integrate them in the household. Finally, the list ends with the head, which can be both an emblem of attractiveness of primary importance and, equally, the relegated container of intellect. 
3 The marketing process of clothes and ornaments inherently sells, attached to these goods, the female body. Together they construct a text that society encodes. A text is a piece of written material regarded as preserving the authentic form of a particular work. The words contained are connected articulating a discourse. It is a subject of study that should denote appropriate and significant emotions experienced in human life. The book bounds this context for it to be presented to the public. However, the present article studies a peculiar text: artists' books, which are works 'of art in book form [...] [that convey] an idea in a visual and tactile way [...]. An artist's book is not about art, it is art" (Linn, 27). A simile between the book and the dressed woman prevails in the art pieces analyzed, as their pages are made of fabric, which is produced by interlacing threads. The thin strands contain here the stories of women held within shaped spaces: bodies artificially altered or oppressive households. Both areas are mainly bedecked with lace; that is, clothes and home décor garnished with lace; lace is a term that comes from the Latin laqueus, which means noose. That is, women and home are gradually trimmed as they are trapped and strangled by the same processes of beautification.

4 The artist considered in this study is Tamar Stone, born in New York in 1962. Stone already has a wide curriculum of public collections in museums and galleries in the United States, Canada and Europe. This year she has already launched four exhibitions at the Allen Library, WA, the Islip Art Museum, NY, the Henry Art Galley, NY, and at the Essex Art Center, MA. Equally, her art has received reviews in specialized blogs, magazines and journals such as The New York Times. She won the New York Foundation for the Arts Artist Fellowship in 2001, and has also been awarded on numerous occasions for her films. She commenced her studies at Washington University School of Fine Arts finishing her degree in 1982. She later completed a Bachelor of Fine Arts at the Pratt Institute in Brooklyn in 1992. Stone finally graduated with an MFA in Film Productions from the University of New York in 1990.

5 The artists claims in her official Website that appearances and physical restrictions on the female body function as inspiration due to her personal experience of wearing a brace throughout most of her teenage years to correct her Scoliosis, and later, as an adult, to cure a spinal condition (<My Background and These Projects>). The pain and discomfort undergone, developed in her a sensitivity towards the narratives of encaged female bodies. She honed her creative appreciation by gradually approximating the sensual experience of clothing and bed linen. Her early Paper Books used sheer materials to superimpose images and texts. In this collection she had already reflected upon the body and its limitations. However, it would be her Corset Works, artists' books made out of vintage corsets and fabrics that the reader undresses in order to read, the ones that would most effectively activate perceptual skills. Stone explains that she "wanted the stories to become more 3-D, to become part of the fabric, in order for the textile to tell the stories" ( $<$ Feminist Artist Statement $>$ ). Consequently, to read the lives of the women embedded in these books, not only must the pages be turned but, in unison, the layers of fashion, medicine and society imposed on them must also be turned and read. Tamar Stone, hence, collects, through used garments, advertisements, personal diaries and old pictures, the unaccounted histories of women, bringing them back onto the pedestal of cultural heritage and memory. The silent tales are handled by the reader who prevents them from fading away. 
The artist's interest in material culture and the history of artifacts emerges in her Bed Works. These are installations in the form of different sized beds. Pillowcases, covers, sheets and mattresses are embroidered or printed with texts, pondering on the effects of housework in women's physic and psychology. Stone clarifies the origin of this collection:

I believe that the bed is the center of the home. Historically our life cycle began and ended in the bed, [...]. In the second half of the 20th century so much of our lives have been taken out of the home and moved to places where we become handled and managed by institutionalized specialists. Because of these things, I became interested in the stories of women and their beds. In order to read these stories, one must become intimately involved with the bed, pulling back the covers to "turn the pages", unmaking the bed. The only way to close the story is to re-make the bed, mimicking the actions of housework that women have been doing for centuries. (<Culture Hall>)

Thus, the artist is redefining the concept of the book, of the female body, fashion and housework, and, above all, the process of reading. She believes that "a narrative unfolds with or without a traditional "spine" to support a physical book" ( $<$ Culture Hall>). Tamar Stone disintegrates the dictatorial presence of the spine as the pages of her books overlap, and texts and images partly cover each other so that the perfect body image is questioned, fears are exposed and housekeeping is deconstructed. All this occurs as the reader dismantles the established shapes of books, corsets and beds.

Women have long been the objects of mainstream social architecture. Their bodies have been molded and framed, like buildings under construction. And in resonance with the same simile, like interiors, they have been decorated, disguising their original distinctive natures. The pressure exerted by tightening dresses and the overbearing presence of accessories has annulled the female voice of individuality. As a consequence, the female body was turned into a white canvas encoded by others (Davies, 61). Accordingly, women have been gagged, as surfaces to be painted, covered with an alien message, or sewn in patterns, having words forced into their essence as the discourse is pierced through them. It would not be a surprise then to state that "women learn to see themselves and other women through men's eyes, thereby becoming accidental policemen of the very power structure that excludes them [...] they are [...] alienated from the very bodies by which they have been trapped" (Davies, 62). The text that is inscribed in their bodies becomes the filter through which they read the world. Tamar Stone's pieces intermingle these cruel judgments on women's bodies, manners and duties with the unvoiced demands and claims that inhabited their minds in silence.

9 The consequence of this sculpting process in the hands of the male establishment of power is a sexualized depiction of women. Thus, if women become replicas of men's ideals, they risk becoming a sexual toy, and clothes have been an effective means by which male artists have produced images of women with particular kinds of erotic innuendos (Mullins, 122). Projecting sexual desire in the silent text of female corporeality drastically simplifies the idiosyncrasies of women. Tamar Stone shows how women passively consumed the influencing messages about their appearances:

[Ergo they] develop a false body image because they internalize [...] an objectified representation of the female body. The development of a corporeal sense of self thus depends on an act of consumption [...] Both the idea of the "false body" and the phallic Imaginary suggest that women may have a particular propensity for developing an 
inauthentic body image due to external phallocentric representations of the female body. (Bray, 52-54)

The books perform this disordered mental perception through the use of multilayered collages of merging materials and printing techniques. The final effect blurs any faultless silhouettes as the lines traverse images and texts that contradict or complement each other. The neat chaos represents the psychosis provoked by physical and movement impositions on women. Her Paper Book To exert (as oneself), created in 1999 , perfectly illustrates the complex elaboration that results from the combination of imbricated elements:

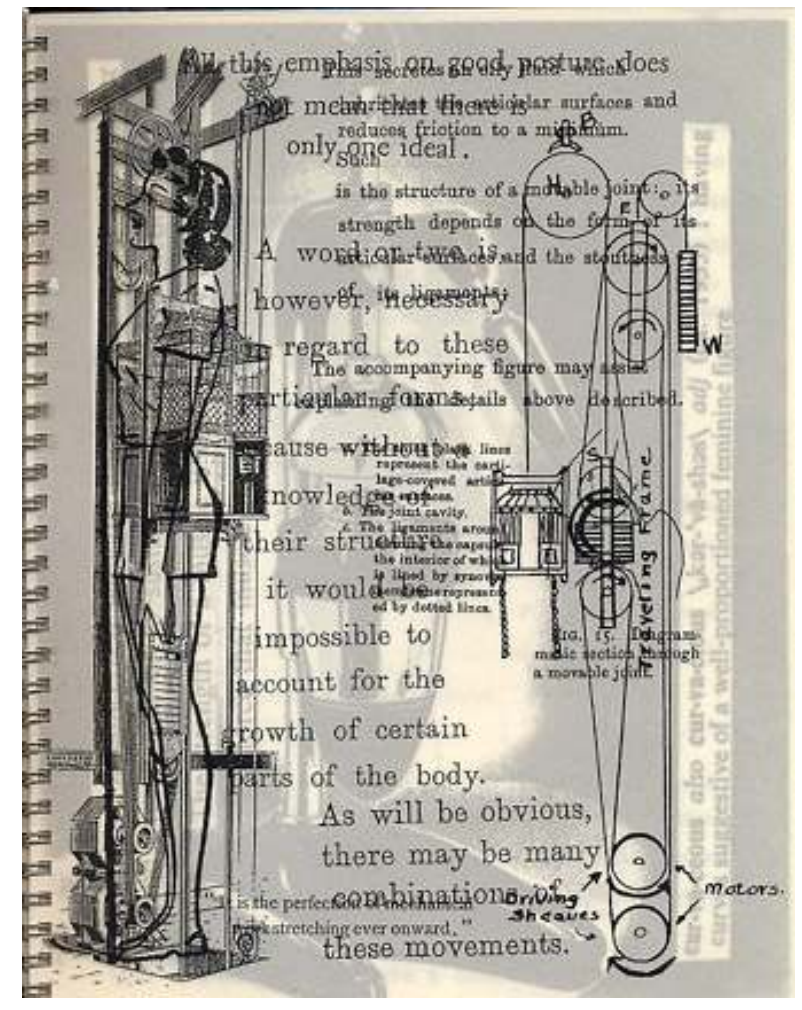

The strategy to soothe this unstable perception of the self finds its way in a rewriting of history. Tamar Stone recycles ingrained cultural messages and the pages that publicized them to create a montage where plurality pertains. "The effect of reading these multi-voiced texts can be disconcerting, [...] [being] difficult to assess where each of the different overlapping images originates and which images provide accurate and which distorted views of reality" (Kogan, 4). The confusion of the reader functions as a cathartic process, which grants women the opportunity to manipulate the propaganda that sold untrue female representations to write this time around a realistic body made of the imperfections of nature; which are the same defects that provide the piece of art with the quality of uniqueness. Ergo, these books hamper any attempts of massproduction of gender ideals. 


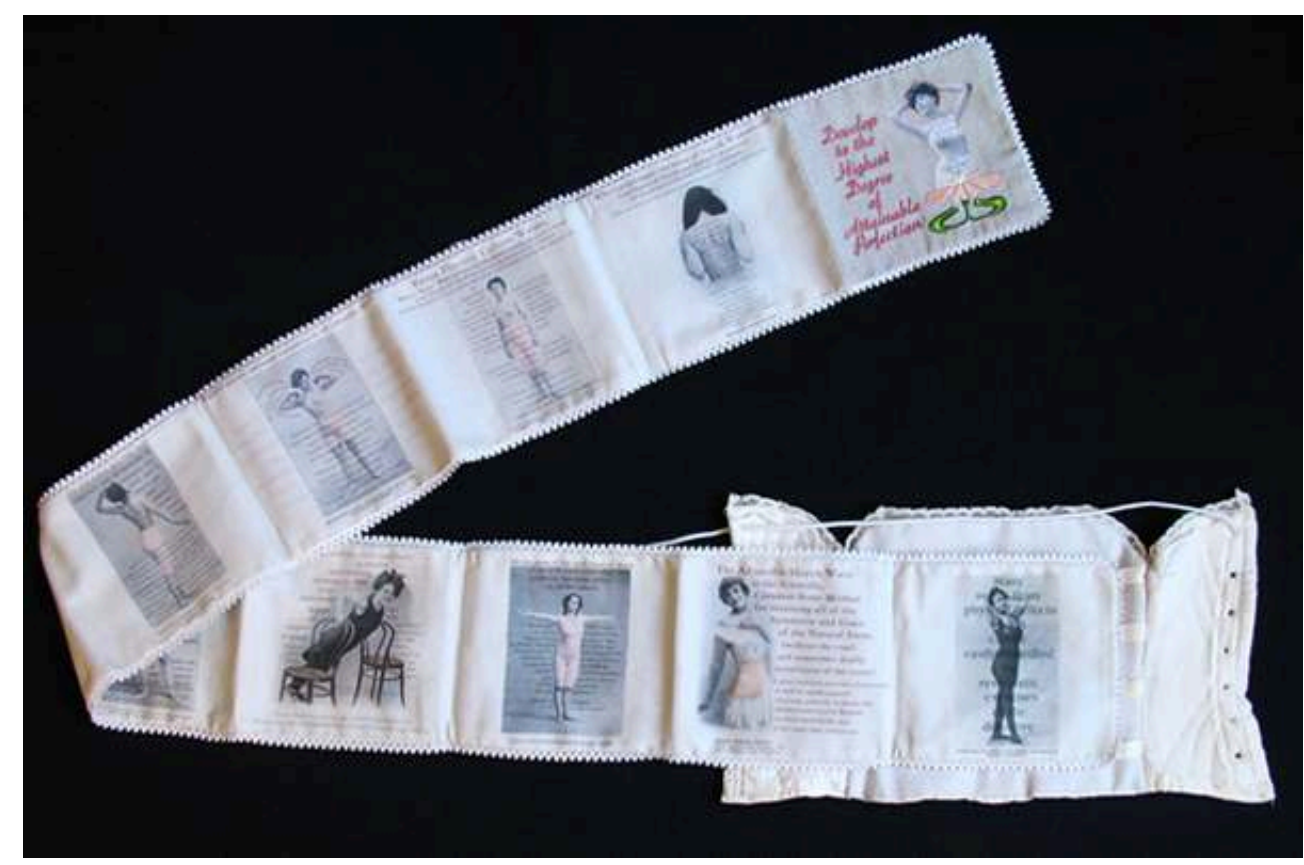

The most characteristic component of Stone's collections is the corset. Artists have broadly analyzed this object of fetish and orthopedics. The feature that triggers inspiration presents a double nature: the alluring intimacy of an attire that becomes a second skin, forbidden and hidden and, on the other hand, the grotesque fascination found in an artificial corrector of a deformed spine. Beauty and freakish anatomy find a common case in the corset. Among many others, the paintings of Henri de ToulouseLautrec and the photographs of P. Horst have captured how the "corset sexualizes the body in form and action; in so doing it becomes itself sexualized, in its material components and the associations they arose, and in the manner in which the garment as a whole is put on or off" (Kunzle 28). Conversely, the excruciating distortions in the musculoskeletal system have been denounced for instance by painter Frida Kahlo and conceptual artist Sarah Misselbrook. Frequently, women's experiences with corsets have appeared in private written reports. The female inked memories dominate the archives that Tamar Stone carefully researched. The paradox found in these reports is double. Firstly, men who advertised against corsets indirectly perpetuated the sexist tokenism. Luke Limner, for instance, who published a study of the negative health effects of corsets in 1874, strengthened the doctrinaire symbol by describing the victims as frail beauties incarcerated (Summers, 127). Secondly, women found pleasure in the male admiration created by the appearance in mirrors with the use of the corset; that is, they enjoyed embodying the canonical image of beauty. Thus, they often encouraged younger generations of women to internalize the use of the corset as part of their essential and, almost, obligatory beauty routines and to pass it on as part of their legacy. 


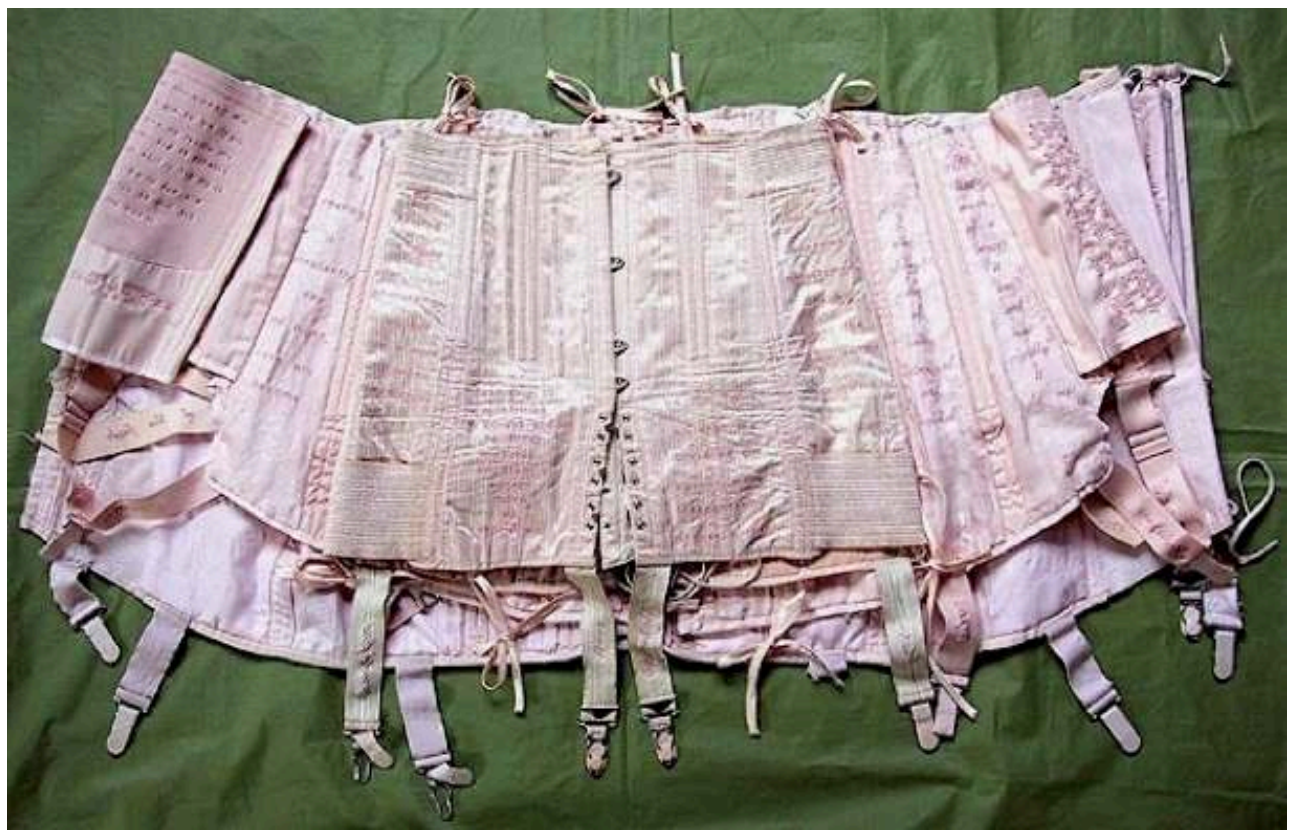

Tamar Stone complicates further this initial duality by including a range of ruptures in the books, in the pages that encapsulate the body as a text. In this way, women will incorporate new perceptions of outer appearance, art, and even men as they elaborate reflections on their physical entity (Bowers, 38). The quotes the reader confronts in the pages function as an indirect questionnaire to reevaluate the principles that rule the rooted abstraction of perfection and quintessential body symmetry. Stone's juxtaposition of propaganda, diaries, medical drawings and delicate rags portrays the impossibility of considering the human appearance a tabula rasa. Society has inscribed perceptive messages on the collective imaginary in the same manner that Tamar Stone embroiders silhouettes in silky pages.

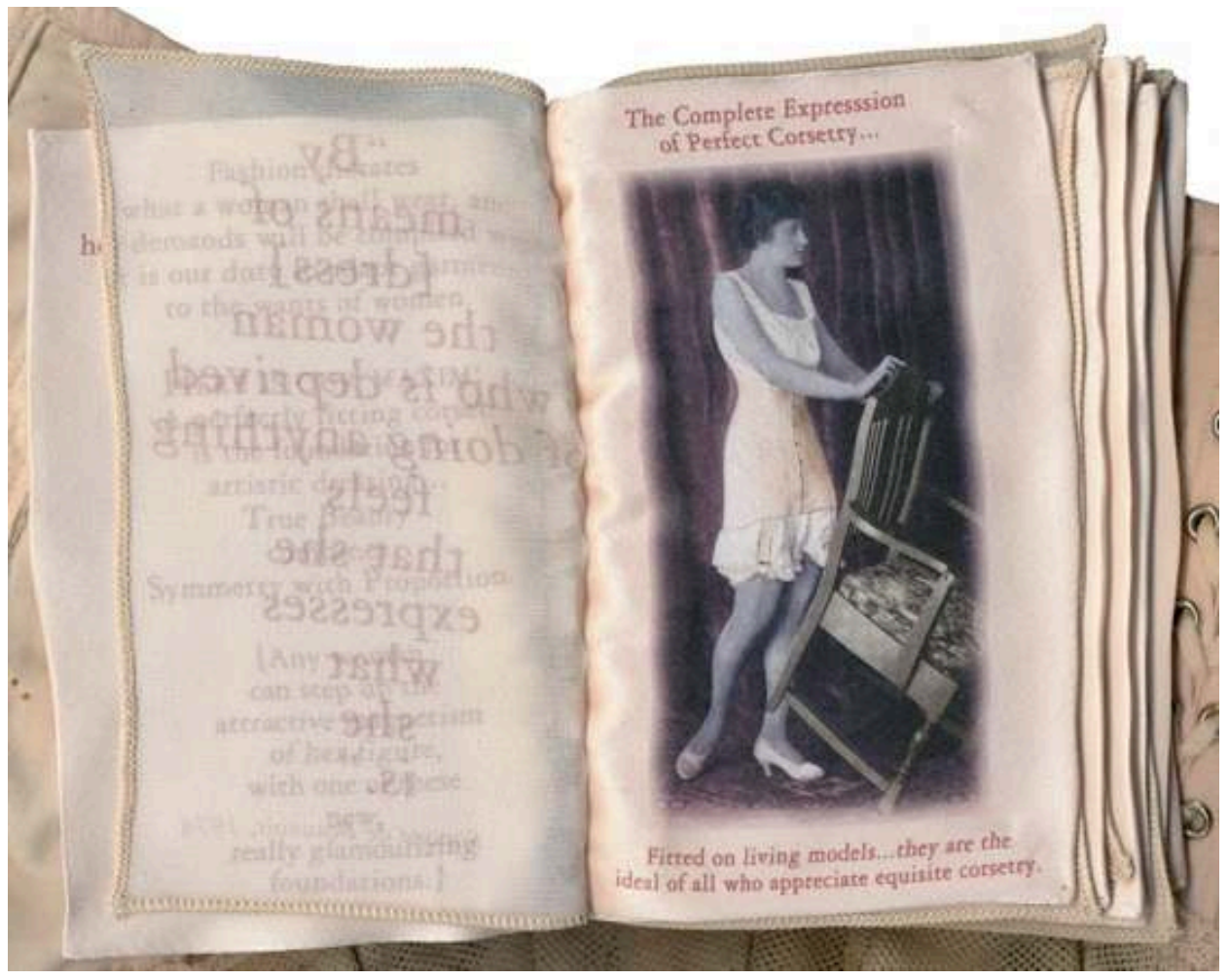


As Grosz states regarding corporeal feminist theories: "the body is a social and discursive object, a body bound up in the order of desire, signification and power" (19). The sewn women's underclothing directly represents female anatomy in Stone's art. These fabrics come from women's most intimate garment, a second skin that is not natural: the corset. It has been artificially created, stitched following a social pattern, and placed over their bodies even before they could argue in favor or against it. The relevance of Tamar Stone's artists' books lies equally in the statement against unprocessed patterns and passive consumption when the commercialized item is the body. Maya Angelou's well-known "Phenomenal Woman" poem describes the female "inner mystery" as a composite of peculiarities and singular details that Stone captures in artistic scrapbooks of proud femininity.

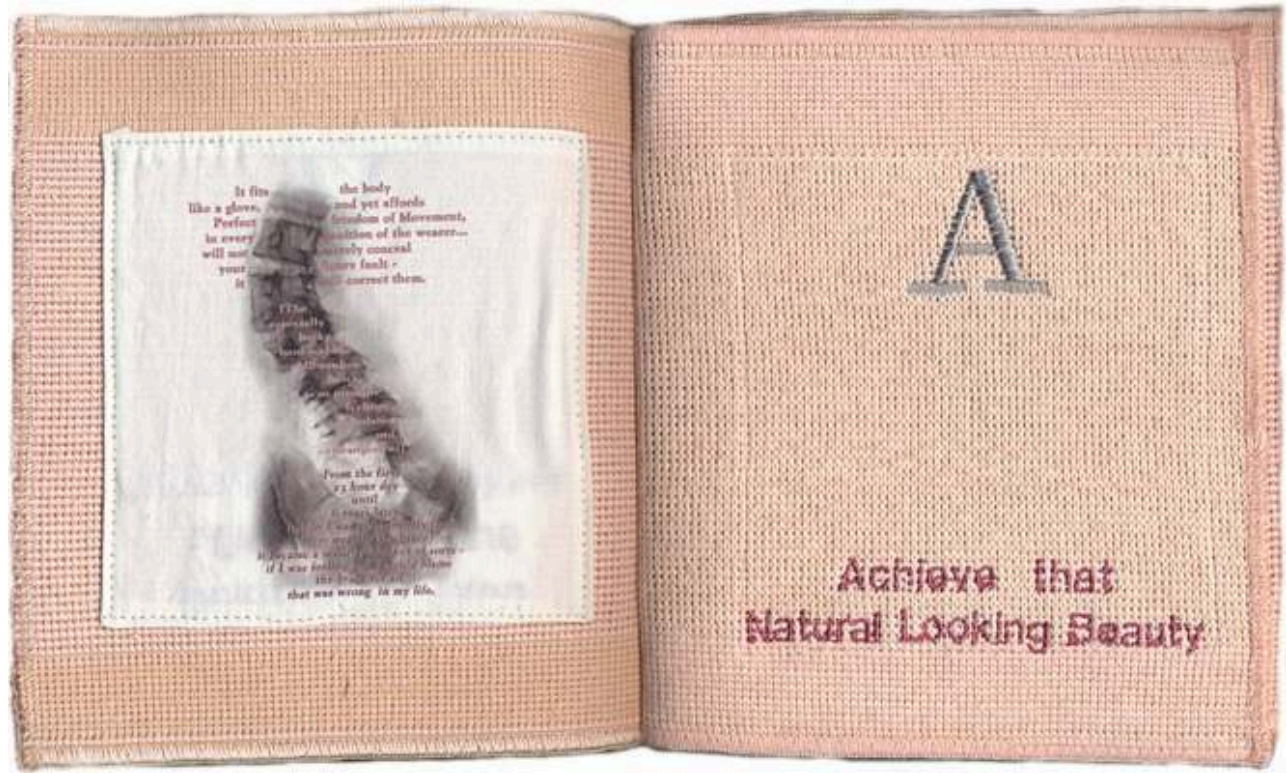

By deconstructing these sexual female pieces of underwear, Tamar Stone also enables a reconsideration of traditional crafts associated with housekeeping and stereotyped gender roles. As social restrictions precluded women's writing from being influential, these accounts remained unshared. Their productive skills were hampered by male domination and the pen and paper were substituted by thread, needle and fabric. Embroidering, sewing, quilting, etc, were unquestionably allowed, as they were part of the household chores. Women subtly displayed their artistic capacities in these pieces, voicing the silent discourses forbidden in circles of power. The complexity of this reading of female crafting emerges in the consideration of the main source of constraint for women: their natural reproductivity. Their body is the origin of creation. Motherhood has tied women to the home; it "imprisoned her in repetition and immanence" (Boulous Walker, 165-166). However, Stone's art portrays the liberating factor of female repetition and generative potential. The repetitive action of sewing, the monotonous activities of housekeeping, such as making a bed, become a writing and reading exercise. Women, hence, reconquer their productivity, turning their stipulated duties into creative processes. In fact, Stone declares in her own artistic feminist statement that the "beautiful yet tortuous constructions give voice to historical objects that constrained them physically or provided the mundane texture of their culturally determined lives" (<Brooklyn Museum>). Consequently, the muzzle 
becomes their text and their platform to perform their public identities. Following, I will exemplify this argument with a close reading of four of Tamar Stone's books.

Her first artists' book creation in 1998 was entitled Your/My... Insecurities are my limbs. The piece is a paper book built with translucent vellum and acetate pages to create an overlaying effect that studies the concept of limbs. The title summarizes the core signification of this work. The possessive pronouns signal the innate necessity of ownership over one's own body and over the desired other. However, when the body is handed over either to an overbearing companion or to the authority of medicine, the passive self is filled with uncertainty as the limbs that permit interaction with the world become indefinite. Hence, a sense of alienation within one's own body arises, as if the limb had been amputated, experiencing the phenomenon of the phantom limb, where the lost part is still sensed. Weiss explains that these cases depend on physical memory, but, equally, on a strong emotion invested in the missing limb. Consequently, "the role that memory plays in the construction of one's present body image(s) can only be understood if the emotional contexts that situate (and stimulate) these memories are also illuminated [...]" (34).

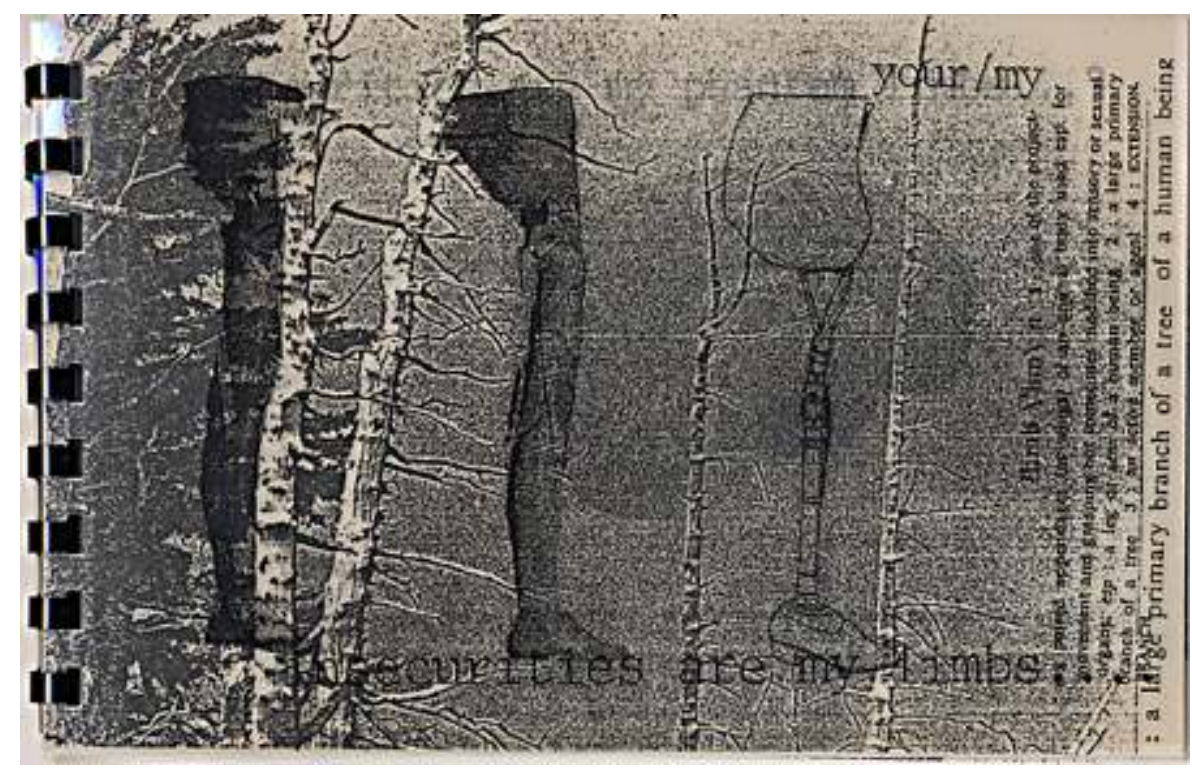

17 Orthopedics reshapes bones, while fashion corsets remodel the figure but, in both cases, anatomy loses entity to be turned into a process, a project of creation controlled by an outer power. The person retains in memory an image that no longer exists. The concept of needing correction is counterpointed with the inclusion in this book of the dictionary entries of the terms "define" and "fault". The shortcomings of the body are beautifully represented by the multiple layers of tree branches and limbs. The arms of nature growing freely partially eclipse artificial limbs. The reverence to perfection is ridiculed and problematized by exposing the frailty of the human body and the apprehension about harm, pain and deformity. The feelings attached to these limbs remain perceptible regardless of the presence of an intrusive entity; thus, humans are highly susceptible to physical alterations. In the page shown bellow, the earth strata are placed in parallel with a human limb. A natural force has displaced some sections and the resulting line is called a "fault line". The terms are neutral. Conversely, a displaced tissue or bone in the body is "condemned". Society publicly censures physical appearances that do not meet the standard. 

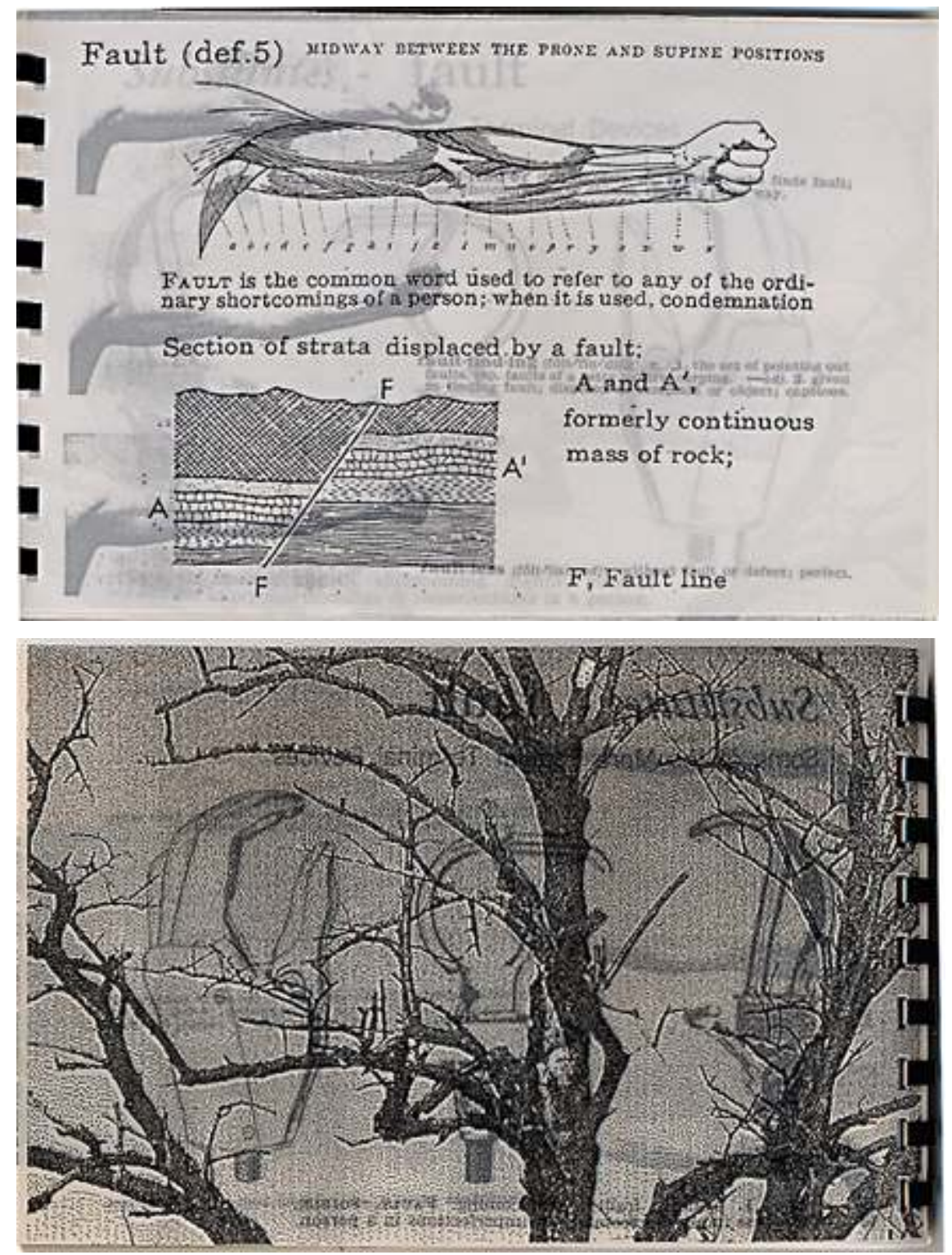

18 Malady and ache inspired Tamar Stone's first life size installation. In 2008 she built a book in the shape of a sanitarium bed, entitled "I've sat and lain in bed for months". She embroidered every element of the bed lining, mattress and pillows with diary entries of women sick with tuberculosis. The artist completed the scene with printed pictures on the covers, Burnitol sputum cups and a Bullseye Brand shot bag. The austerity of this piece becomes apparent in the worn out wooden pieces forming the frame of the bed, the rusty coils, the thin fabrics and plain designs and straight lines. The wood and metal fragments enhance the portrayal of physical pain, as the sturdiness of these materials seems to cruelly enclose the soft bedding, and the chains and coils could be read as sharp physical agony stabbing the mattress.

From one of these diaries, Stone quotes the following:

Even the bed sheets conspired against me, the flannel sheets clinging tenaciously to my pajamas with each move, and the blankets, tucked in all the way up on both sides, forming a tight envelope in which I was held like a vise. I turned my head from side to side, rebelling at the feeling of confinement. (Blanket 1. Front side) 
mile of the vise faithfully represents the imprisonment these women felt when the jaws of science held them unmovable to become a project of investigation, losing their free will. Their head, representing their intellect, is the only feature still pertaining to them. The sensation of incarceration is denoted by the unexpected collocation of two semantic fields that are most frequently unrelated: the bed and discomfort. Tamar Stone explores a new configuration of the bed, where the object is reinterpreted outside of its established symbolism of comfort and protection. It is then thanks to the careful arrangement of her installations that "those definitions [of domestic items] shift depending upon what objects are placed next to each other. No definition, therefore, is ever absolute" (Greeley, 51); and, thus Stone challenges the beholder with this reassessment.

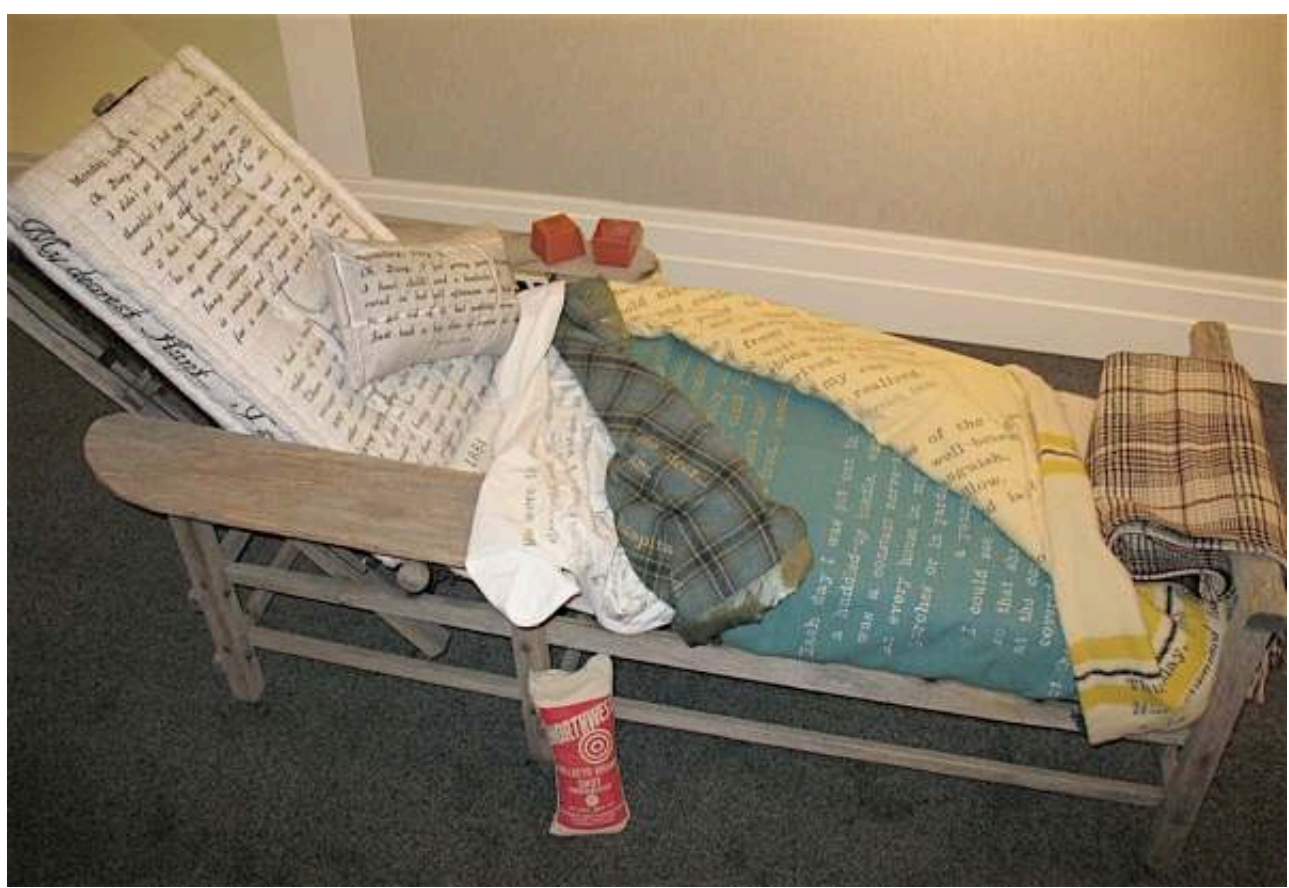

In 2003 Tamar Stone completed her bed piece H.T.W.E. [“...his thanks was enough..."], modeled after folding army cots. The artist pays homage to the nurses that collaborated during the Civil War. The basis for this project was the figure of Florence Nightingale, who fought to redefine the role of women in hospitals in the nineteenth century. The stories that cover the different pieces of this bed come from female experiences in battlefields. Two of the accounts included are Louisa May Alcott's and Sarah Emma Edmonds's. The latter served the Union Army disguised as a man. Alcott's service in Georgetown, D.C., is described here:

I spent my shining hours washing faces, serving rations, giving medicine, and sitting in a very hard chair, with pneumonia on one side, diphtheria on the other, two typhoids opposite and a dozen dilapidated patriots hopping, lying, and lounging about, all staring more or less at the new "nuss," who suffered untold agonies, but concealed them under as matronly an aspect as a spinster could assume, and blundered through her trying labors with a Spartan firmness, which I hope they appreciated, but am afraid they didn't. (Pillowcase front)

These nurses were undaunted by the harsh conditions of the war, regardless of the performance of motherly duties, typically enforced on women. They led a frugal existence and expressed no complaints, demonstrating equal strength and courage to 
the male soldiers, who were oblivious to the gender transformation occurring around them. To illustrate the contrast between the elaborate decorations of women's dresses and homes and the plainness of nurses, Tamar Stone employs rough fabrics of drab colors. The wool and cotton cloths are stained and filled with moth holes, as a reflection of the damaging conditions undergone. Masculine elements such as metal buttons, nails or leather straps remind the audience of male belts and reinforce the dark green hues associated with soldiers and the printed charts, symbols of scientific and statistic work, not frequently linked to the duties of nurses.

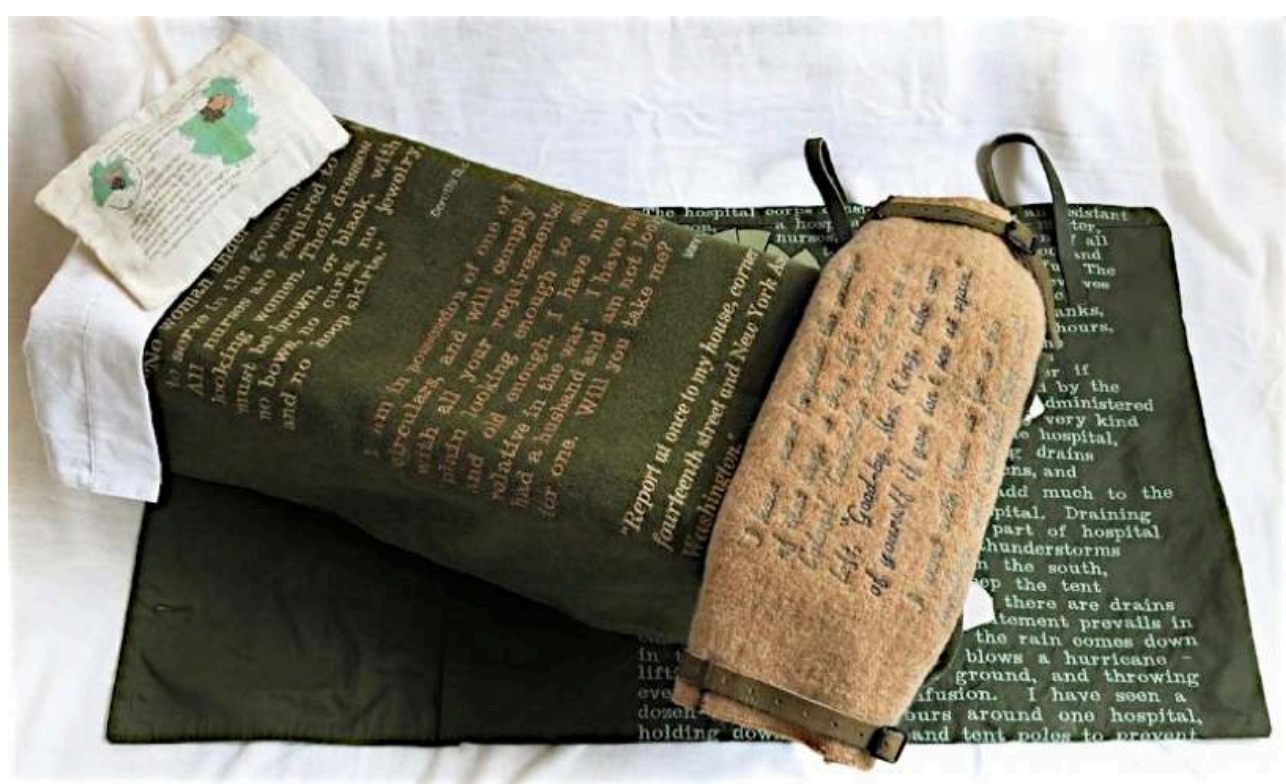

Primarily, Tamar Stone devotes her creativity to rewriting women's history, which cannot be detached from their bodies and their gender roles in society. Consequently, her analysis liberates the text containing female lore from established delimitations. Ergo, in her latest corset book, Mechanics of Beauty, 2012, she embroiders the following words: "We so invariably see the female body distorted into artificial shapes that taste has been perverted and our eyes have lost the power to distinguish its true beauty" (Inside corset. Right side). A fully animated display of the book is available for readers to experience the articulation of the object (<Mechanics of Beauty Video>). She was inspired by the studies developed by John Harvey Kellogg on the negative effects of corsets. The graphic recordings of men and women's breathings are presented together with female silhouettes that encase textual reflections on anatomy. The wording is juxtaposed with images of spines, which she calls "the line of beauty", and drawings of mechanisms of talking and walking dolls. The toys designed for girls represent the ideal of female beauty but Stone questions it by forcing the reader to face the violence perpetrated against the nature of these bodies with the use of corsets. The straight lines contrast the curves of the real bodies, which are presented through multilayered pages of vintage flannel and sheer organza, in order to accommodate the perfection outlined by fashion's tyranny. 


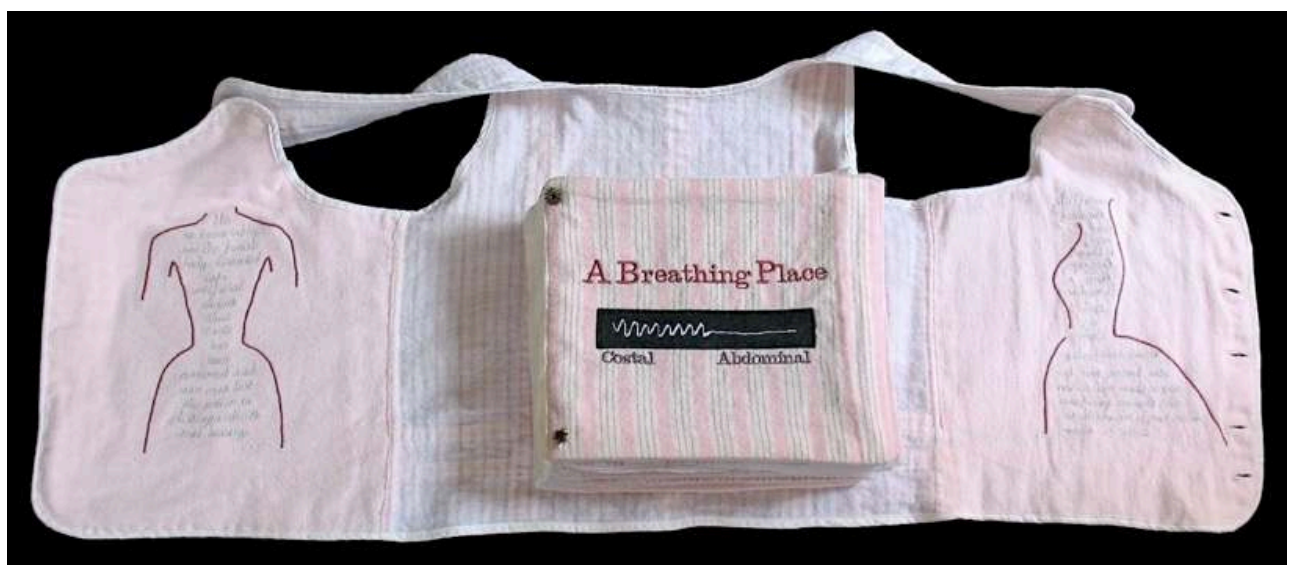

The empathic emotions triggered by Tamar Stone's art originate from her successful enterprise in recycling propaganda, diaries and fashion to embroider and sew together books that provide the audience with a dignified space to partake in a common exchange of insecurities and imperfections. In this manner, Stone's artists' books function as a rebalancing agent for the grotesque images instilled in the male and female unconscious through society's corporeal demands. The delicacy of Stone's stitches, fabrics and threading embellishment redefine the female body voicing the pain and courage captured in these vintage fragments of women's history.

Work Cited.

ANGELOU, Maya, "Phenomenal Woman", Phenomenal Woman: Four Poems Celebrating Women, New York, Random House, 1978.

ATWOOD, Margaret, "The Female Body", The Female Body: Figures, Styles, Speculations, Ed. Laurence Goldstein, Ann Arbor, University of Michigan Press, 1997.

BOWERS, Susan R., “The Witch's Garden: The Feminist Grotesque", Sexuality, the Female Gaze, and the Arts, Eds. Ronald Dotterer and Susan R. Bowers, Selinsgrove, PA, Susquehanna University Press, 1992.

BRAY, Abigail and Claire Colebrook, "The Haunted Flesh: Corporeal Feminism and the Politics of (Dis)Embodiment", Signs, vol. 24, No. 1 (Autumn), University of Chicago Press, 1988, 35-67.

DAVIES, Madeleine, "Margaret Atwood's Female Bodies", The Cambridge Companion To Margaret Atwood, Ed. Coral Ann Howells. Cambridge, Cambridge University Press, 2006.

GREELEY, Robin Adèle, "Image, Text and the Female Body: René Magritte and the Surrealist Publications", Oxford Art Journal, vol. 15, No. 2, Oxford University Press, 1992, 48-57.

GROSZ, Elizabeth, Volatile Bodies: Towards a Corporeal Feminism, Bloomington, Indiana University Press, 1994.

KOGAN, Deborah, "Profile/Tamar Stone: Telling Women's Stories", Apmersand, vol. 26, No. 2 (Winter), Green Chair Press, 2009, 1-6. http://www.greenchairpress.com/blog/?p=772 (last accessed on October $\left.15^{\text {th }}, 2013\right)$.

KUNZLE, David, Fashion and Fetishism, Totowa, NJ, Rowman and LittleField, 1982.

LINN, Nancy, “Women Artists' Books”, Woman's Art Journal, vol. 3, No. 1 (Spring - Summer), Woman's Art Inc., 1982, 27.

MEISS, Gail, Body Images: Embodiment as Intercorporeality, New York, Routledge, 1999.

MULLINS, Edwin, The Painted Witch. Female Body: Male Art, London, Secker \& Warburg, 1885. 
STONE, Tamar, "Feminist Artist Statement", Elizabeth A. Sackler Center for Feminist Art: Feminist Art Base : Tamar Stone, Brooklyn Museum, http://www.brooklynmuseum.org/eascfa/ feminist_art_base/gallery/Tamar_Stone.php (last accessed on October 15th, 2013).

-“Tamar Stone", Culture Hall,

http://culturehall.com/tamar_stone/

biography;jsessionid=12BF40D288ECF6A37CFFA411B06F0191 (last accessed on October 15th, 2013).

- "My Background and These Projects", http://www.tamarstone.com/Background+Contacts.html (last accessed on October 15th, 2013).

SUMMERS, Leigh, Bound to Please: A History of the Victorian Corset, Oxford, Berg, 2001.

WALKER, Michelle Boulous, Philosophy and the Maternal Body: Reading Silence, London, Routledge, 1998

\section{ABSTRACTS}

This article analyzes American visual artist Tamar Stone's artists' books collections. These exquisite pieces challenge the female ideal of beauty and established gender roles, through representations of the body, anatomic and medical drawings and personal accounts; all of which are either printed or embroidered on vintage fabrics that function as layers of women's history. Tamar Stone creates three-dimensional and sensuous books that provide the reader with an artistic platform to project anxieties about physical appearances, social duties, health, pain and memory.

\section{INDEX}

Subjects: Trans'Arts

Keywords: Artists' books, American female visual artists, female rewriting in Art, female body, corsets, distorted bodies, ideal beauty, woman's domestic body, resting place, corporeal feminism

\section{AUTHOR}

\section{CANDELA DELGADO-MARÍN}

University of Seville 